\title{
ASI sebagai faktor protektif terhadap autisme
}

\author{
Breastfeeding as a protective factor against autism \\ Kornelius Dandung Bawono ${ }^{1}$, Elisabeth Siti Herini ${ }^{1}$, Setya Wandita ${ }^{1}$
}

\begin{abstract}
Background: The prevalence of autism has risen in the last decades. Risk factors of autism remain controversial and were thought to be multifactorial. One hypothesis stated that it may be caused by leaky gut theory and long chain polyunsaturated fatty acid deficiency. Optimal duration of breastfeeding has been proven to reduce risk of gastrointestinal infection and improve child's cognitive ability.

Objective: To study the protective effect of optimal duration of breastfeeding to reduce the risk of autism.

Methods: A matching case-control study was conducted in Yogyakarta and Magelang during 2008. Inclusion criteria of case group were all children with autism (diagnosed based on DSM-IV TR criteria), aged 3-10 years. Autistic children with distinct genetic disorder were excluded. Control group was matched on gender, age, and their residence. Breastfeeding pattern and other related information were obtained by direct interview. McNemar test, conditional multivariate logistic regression, and Maentel-Haenszel test were used to find factors that are significantly associated with autism.

Results: There were 52 children with autism and 104 control subjects. The mean age was 5 years old. The analysis revealed that breastfeeding duration for less than 6 months was a significant risk factor for autism $\left(O R_{M H}=2,05 ; R K\right.$ 95\%:1,03-5,01), as well as history of abnormal birth weight (OR=3,36; RK 95\%:1,37-8,44). There was dose-effect gradient as breastfeeding duration affected risk of autism. There was no differences on the duration of exclusive breastfeeding between the two groups.
\end{abstract}

Conclusion: Breastfeeding duration of less than 6 months was a significant risk factor for autism.

KEY WORDS autism, autism spectrum disorder, breastfeeding, breast milk duration

\begin{abstract}
ABSTRAK
Latar belakang: Prevalensi autisme meningkat dalam beberapa dekade terakhir. Faktor risiko autisme masih kontroversial, diduga multifaktorial. Salah satu hipotesis penyebab terjadinya autisme adalah kebocoran dinding usus dan defisiensi asam lemak rantai panjang. Durasi pemberian ASI yang optimal telah terbukti menurunkan risiko terhadap infeksi gastrointestinal serta meningkatkan kecerdasan dan perkembangan anak.

Tujuan: Mengetahui efek protektif pemberian ASI yang optimal untuk mengurangi risiko kejadian autisme.

Metode: Penelitian dilakukan dengan desain kasus-kontrol berpasangan, selama tahun 2008 di Yogyakarta dan Magelang. Kriteria inklusi kelompok kasus adalah anak berumur 3-10 tahun dengan autisme (diagnosis ulang berdasarkan DSMIV-TR). Anak autisme dengan kelainan genetik yang khas dieksklusi. Matching dilakukan pada jenis kelamin, usia, dan tempat tinggal. Pengambilan data dilakukan dengan kuesioner melalui wawancara langsung. Uji hipotesis yang digunakan adalah uji McNemar, uji regresi logistik, dan uji Maentel-Haenszel.

Hasil: Sebanyak 52 kasus dan 104 kontrol terpilih menjadi subjek penelitian. Rerata umur subjek adalah 5 tahun. Setelah dilakukan analisis faktor pengganggu, durasi pemberian ASI kurang dari 6 bulan merupakan faktor risiko terhadap autisme $\left(O R_{M H}=2,05 ;\right.$ RK 95\%:1,03-5,01). Terdapat dose-effect gradient pada lama pemberian ASI. Faktor risiko lain yang ditemukan adalah riwayat berat lahir tidak normal $(O R=3,36 ; R K 95 \%: 1,37-8,44)$. Durasi pemberian ASI saja tanpa makanan atau minuman tambahan minimal selama 4 bulan tidak ditemukan berbeda bermakna antara kedua kelompok.
\end{abstract}

Kesimpulan: Durasi pemberian ASI kurang dari 6 bulan merupakan faktor risiko terjadinya autisme.

KATA KUNCI: autism, autism spectrum disorder, ASI, durasi menyusui

\section{PENDAHULUAN}

Gangguan spektrum autisme atau Autism Spectrum Disorder (ASD) adalah suatu sindrom gangguan tumbuh kembang anak yang kompleks, ditandai dengan adanya trias klasik yaitu adanya gangguan keterlambatan bicara, gangguan dalam berhubungan dengan lingkungan, dan adanya perilaku yang terbatas atau berulang, yang muncul pada usia (onset) kurang dari 3 tahun (1).

Jumlah anak dengan autisme meningkat pada dekade terakhir di seluruh dunia, dari 5-10/10.000 anak pada dekade 1980-an menjadi 6/1000 anak pada dekade 2000-an. Prevalensi ini lebih tinggi dari prevalensi gangguan neurologi lain seperti spina bifida, sindrom

\footnotetext{
1 Bagian Ilmu Kesehatan Anak, Fakultas Kedokteran Universitas Gadjah Mada / Rumah Sakit Umum Pusat Dr Sardjito, Jl. Kesehatan 1 Sekip, Yogyakarta 55281, e-mail: dandungbawono@hotmail.com, herini_es@yahoo.com, tioding@yahoo.com

* correspondence author
} 
down, dan kanker. Kenaikan insidensi autisme tidak hanya terjadi di Amerika Serikat dan Inggris, namun juga di berbagai daerah dunia, termasuk di Arab, Afrika, dan Asia (1). Di Indonesia belum ditemukan angka pastinya, namun kenaikan insidensinya telah lama diperhatikan di tempat praktik dokter dan sekolah khusus autisme (2).

Hingga saat ini, faktor risiko autisme masih kontroversial. Penyebabnya diduga multifaktorial, melibatkan faktor genetik dan lingkungan. Salah satu hipotesis menyebutkan adanya peranan leaky gut dan defisiensi asam lemak rantai panjang (1).

Air susu ibu (ASI) adalah sumber nutrisi paling penting pada masa bayi. World Health Organization (WHO, 2001) merekomendasikan pemberian ASI yang optimal adalah inisiasi dini, ASI eksklusif sampai 6 bulan, dan pemberian ASI hingga paling tidak umur 2 tahun. Rekomendasi dari American Academy of Pediatrics (2005) menyatakan bahwa pemberian ASI harus dilakukan paling tidak sampai bayi berusia 12 bulan $(3,4)$.

Beberapa manfaat ASI diantaranya mengurangi risiko infeksi gastrointestinal, mengurangi kejadian alergi, dan meningkatkan kecerdasan anak dengan mencukupi kebutuhan asam lemak rantai panjang (5-10). Beberapa referensi menyatakan bahwa pemberian ASI dapat menurunkan kejadian autisme. Namun, penelitian yang mencari hubungan antara kedua faktor ini belum banyak dilakukan (11).

Hingga saat ini, baru ada 2 penelitian dengan desain kasus kontrol yang meneliti hubungan antara durasi pemberian ASI dan risiko autisme. Kedua penelitian tersebut menemukan hasil bahwa durasi pemberian ASI yang tidak optimal memberikan risiko terhadap autisme. Namun kedua penelitian ini mengandung kelemahan dari segi metodologi, sehingga penelitian dengan desain yang lebih baik lagi perlu dilakukan untuk mendukung kesimpulan adanya hubungan antara kedua faktor ini $(12,13)$.

\section{BAHAN DAN METODE}

Penelitian ini menggunakan rancangan studi kasus kontrol, dengan matching pada variabel usia, jenis kelamin, dan tempat tinggal. Studi ini membandingkan antara anak autisme (kelompok kasus) dengan anak tanpa autisme (kelompok kontrol). Penelitian dilakukan selama tahun 2008 di sekolah khusus autisme Bina Anggita di Yogyakarta dan Magelang ditambah dengan korespondensi pribadi. Besar sampel dihitung dengan perhitungan besar sampel untuk studi kasus kontrol berpasangan (14). Keseluruhan jumlah subjek penelitian ini adalah 156 anak, terdiri dari 52 anak dengan autisme (kasus) dan 104 anak tidak dengan autisme (kontrol).

Kriteria inklusi kelompok kasus adalah semua anak yang didiagnosis autisme baik laki-laki maupun perempuan dan berusia antara 3 hingga 10 tahun. Peneliti melakukan diagnosis ulang dengan menggunakan kriteria diagnosis autisme sesuai Diagnostic and Statistical Manual of Mental Disorder IV (DSM IV) (15). Kriteria eksklusi adalah anak autisme yang berhubungan dengan kelainan murni genetik, misalnya sindrom Rett, tuberosklerosis, neurofibromatosis, Fragile-X Syndrome, gangguan metabolik atau infeksi kongenital yang khas seperti sindrom rubella, ibu dari anak telah meninggal dunia atau karena berbagai sebab tidak bisa dimintai keterangan, domisili tempat tinggal tidak memungkinkan untuk mencari kontrol, dan keluarga menolak untuk terlibat dalam penelitian.

Kriteria inklusi kelompok kontrol adalah anak tidak dengan autisme dan memenuhi kriteria matching dengan kasus. Kriteria eksklusi kelompok kontrol adalah anak-anak yang mempunyai gangguan perkembangan atau gangguan tingkah laku dalam bentuk apapun, ibu telah meninggal dunia atau karena berbagai sebab tidak bisa dimintai keterangan, dan keluarga tidak bersedia menjadi subjek penelitian.

Variabel bebas dalam penelitian ini terdiri dari pola pemberian ASI selama 4 bulan pertama (diberikan atau tidak), tingkat pendidikan ibu (sarjana atau bukan sarjana), tingkat pendidikan ayah (sarjana atau bukan sarjana), urutan lahir (anak sulung atau bukan), usia ibu waktu melahirkan (kurang atau lebih dari 35 tahun), riwayat prematuritas (ada atau tidak), riwayat berat bayi lahir rendah (kurang atau lebih dari 2500 gram), dan riwayat pemberian vaksinasi measles, mumps, rubella (MMR) (diberikan atau tidak). Data tersebut diperoleh dengan menggunakan kuesioner.

Bias yang mengancam penelitian dengan desain kasus kontrol adalah bias seleksi dan bias ingatan. Usaha yang dilakukan untuk meminimalisasi bias ingatan ini yaitu dengan melakukan pembatasan umur dalam kriteria inklusi (yaitu 3-10 tahun), melakukan wawancara langsung dengan ibu tentang pola pemberian ASI anaknya, melakukan konfirmasi pada anggota keluarga lain bila memungkinkan, dan penyusunan metode pertanyaan kuesioner yang terstruktur yang memungkinkan peneliti untuk mendeteksi adanya kesalahan ingatan. Analisis data dilakukan dengan uji McNemar, uji regresi logistik bersyarat, dan uji Maentel-Haenszel.

\section{HASIL}

Rerata umur subjek adalah 5 tahun 3 bulan, usia termuda adalah 3 tahun dan usia tertua adalah 9 tahun. Sebagian besar subjek bertempat tinggal di wilayah Kotamadya Yogyakarta dan Sleman (Tabel 1). Autisme infantil merupakan jumlah terbanyak dari kelompok kasus, dibandingkan sindrom Asperger dan Pervasive Developmental Disorder-Not Otherwise Specified (PDD-NOS). Pada kelompok kasus, laki-laki ditemukan lebih banyak dibandingkan perempuan dengan rerata perbandingan 2:1. 
Tabel 1. Karakteristik demografi subjek penelitian

\begin{tabular}{|c|c|c|c|c|}
\hline Variabel & $\begin{array}{l}\text { Kasus } \\
(n=52)\end{array}$ & $\begin{array}{l}\text { Kontrol } \\
(n=104)\end{array}$ & $\mathbf{p}$ & $\begin{array}{c}\text { OR } \\
\text { (RK 95\%) }\end{array}$ \\
\hline Umur (tahun)* & $\frac{\text { Mean (SD) }}{5,3 \pm 1,4}$ & $\frac{\text { Mean (SD) }}{5,3 \pm 1,4}$ & - & - \\
\hline $\begin{array}{l}\text { Jenis kelamin* } \\
\text { Laki laki } \\
\text { Perempuan }\end{array}$ & $\begin{array}{l}35(67,3 \%) \\
17(32,7 \%)\end{array}$ & $\begin{array}{l}70(67,3 \%) \\
34(32,7 \%)\end{array}$ & - & - \\
\hline $\begin{array}{l}\text { Diagnosis } \\
\text { Autisme infantil } \\
\text { Asperger } \\
\text { PDD-NOS }\end{array}$ & $\begin{array}{c}44(84 \%) \\
3(5 \%) \\
5(11 \%)\end{array}$ & - & - & - \\
\hline $\begin{array}{l}\text { Tempat tinggal* }^{*} \\
\text { Kotamadya Yogyakarta } \\
\text { Sleman } \\
\text { Jawa Tengah }\end{array}$ & $\begin{array}{l}20(38 \%) \\
15(28 \%) \\
17(34 \%)\end{array}$ & $\begin{array}{l}40(38 \%) \\
30(28 \%) \\
34(34 \%)\end{array}$ & - & - \\
\hline $\begin{array}{l}\text { Status ekonomi } \\
\text { Di atas UMR } \\
\text { Di bawah UMR }\end{array}$ & $\begin{array}{l}40(76,9 \%) \\
12(23,1 \%)\end{array}$ & $\begin{array}{l}81(77,9 \%) \\
23(22,1 \%)\end{array}$ & 0,89 & $\begin{array}{c}0,9 \\
(0,48-2,09)\end{array}$ \\
\hline $\begin{array}{l}\text { Pendidikan ayah } \\
\text { Sarjana/Diploma } \\
\text { Bukan sarjana }\end{array}$ & $\begin{array}{l}35(67,3 \%) \\
17(32,7 \%)\end{array}$ & $\begin{array}{l}62(59,6 \%) \\
42(40,4 \%)\end{array}$ & 0,35 & $\begin{array}{c}1,97 \\
(0,75-3,78)\end{array}$ \\
\hline $\begin{array}{l}\text { Pendidikan ibu } \\
\text { Sarjana/Diploma } \\
\text { Bukan sarjana }\end{array}$ & $\begin{array}{l}19(36,5 \%) \\
33(63,5 \%)\end{array}$ & $\begin{array}{l}22(21,2 \%) \\
82(78,8 \%)\end{array}$ & $0,04^{\alpha}$ & $\begin{array}{c}2,74 \\
(1,01-5,39)\end{array}$ \\
\hline $\begin{array}{l}\text { Pekerjaan ibu } \\
\text { Tidak bekerja } \\
\text { Bekerja }\end{array}$ & $\begin{array}{l}32(61 \%) \\
20(39 \%)\end{array}$ & $\begin{array}{l}72(69 \%) \\
32(31 \%)\end{array}$ & 0,36 & $\begin{array}{c}0,42 \\
(0,28-1,54)\end{array}$ \\
\hline
\end{tabular}

Keterangan : *dilakukan pencocokan/matching

$\ddagger$ uji McNemar

abermakna secara statistik

PDD-NOS = Pervasive Developmental Disorder-Not Otherwise Specified

DIY = Daerah Istimewa Yogyakarta

UMR = upah minimum regional

Tabel 2. Karakteristik faktor perinatal subjek penelitian

\begin{tabular}{|c|c|c|c|c|}
\hline Variabel & $\begin{array}{l}\text { Kasus } \\
(n=52)\end{array}$ & $\begin{array}{l}\text { Kontrol } \\
(n=104)\end{array}$ & $\mathbf{p}$ & OR (RK 95\%)‡ \\
\hline $\begin{array}{l}\text { Usia maternal tidak ideal } \\
\text { (>35 tahun) }\end{array}$ & $13(25 \%)$ & $18(17,3 \%)$ & 0,25 & $1,59(0,71-3,57)$ \\
\hline Anak pertama & $20(38,5 \%)$ & $28(26,9 \%)$ & 0,14 & $1,69(0,83-3,44)$ \\
\hline $\begin{array}{l}\text { Berat lahir tidak normal } \\
\text { BBLR }(<2500 \mathrm{~g}) \\
\text { BBLB }(>4000 \mathrm{~g})\end{array}$ & $\begin{array}{c}12(23,1 \%) \\
11(92 \%) \\
1(8 \%)\end{array}$ & $\begin{array}{l}9(8,7 \%) \\
8(89 \%) \\
1(11 \%)\end{array}$ & $0,01^{\alpha}$ & $3,16(1,23-8,1)$ \\
\hline $\begin{array}{l}\text { Usia kehamilan tidak normal } \\
\text { Kurang bulan (<37 minggu) } \\
\text { Lebih bulan ( }>42 \text { minggu) }\end{array}$ & $\begin{array}{c}10(19,2 \%) \\
9(90 \%) \\
1(10 \%)\end{array}$ & $\begin{array}{l}7(6,7 \%) \\
6(85 \%) \\
1(15 \%)\end{array}$ & $0,02^{\alpha}$ & $2,83(1,09-7,35)$ \\
\hline Persalinan tindakan & $7(13,5 \%)$ & $16(15,4 \%)$ & 0,74 & $0,85(0,32-2,23)$ \\
\hline Kejadian rawat inap pada saat 30 hari pertama & $4(7,6 \%)$ & $7(6,7 \%)$ & 0,82 & $1,14(0,34-3,65)$ \\
\hline
\end{tabular}

Keterangan: łuji McNemar

$$
\begin{aligned}
& \text { abermakna secara statistik } \\
& \text { BBLR = bayi berat lahir rendah } \\
& \text { BBLB = bayi berat lahir besar }
\end{aligned}
$$

Pendidikan ibu yang tinggi (sarjana/diploma) memberikan risiko terhadap munculnya gangguan autisme dua kali lebih besar dibandingkan pendidikan ibu di bawah sarjana atau diploma dan perbedaan ini bermakna (OR=2,74; RK 95\%:1,01-5,39). Tidak didapatkan perbedaan bermakna pada karakteristik demografi yang lain seperti status ekonomi, pendidikan ayah, dan pekerjaan ibu antara kelompok kasus dan kelompok kontrol.

Pada karakteristik faktor perinatal (Tabel 2), riwayat lahir dengan berat badan tidak normal memberikan risiko tiga kali lebih besar dibandingkan berat lahir normal untuk 
Tabel 3. Durasi pemberian ASI dan risiko terhadap autisme

\begin{tabular}{|c|c|c|c|c|}
\hline Variabel & $\begin{array}{l}\text { Kasus } \\
(n=52)\end{array}$ & $\begin{array}{l}\text { Kontrol } \\
(n=104)\end{array}$ & $\mathbf{p}$ & OR (RK 95\%)‡ \\
\hline $\begin{array}{l}\text { Durasi pemberian ASI } \\
<6 \text { bulan } \\
\geq 6 \text { bulan }\end{array}$ & $\begin{array}{l}30(57,7 \%) \\
22(42,3 \%)\end{array}$ & $\begin{array}{l}44(42,3 \%) \\
60(57,7 \%)\end{array}$ & $0,04^{\alpha \ddagger}$ & $2,01(1,02-3,96)$ \\
\hline $\begin{array}{l}\text { Durasi pemberian } \mathrm{ASI}^{\mathrm{k}} \\
\text { tidak pernah } \\
0-<6 \text { bulan } \\
6-<12 \text { bulan } \\
\geq 12 \text { bulan }\end{array}$ & $\begin{array}{c}9(17,3 \%) \\
21(40,3 \%) \\
17(32,7 \%) \\
5(9,7 \%)\end{array}$ & $\begin{array}{c}9(8,6 \%) \\
35(33,6 \%) \\
37(35,5 \%) \\
23(22,1 \%)\end{array}$ & $\begin{array}{l}0,01^{\alpha} \\
0,16 \\
0,39\end{array}$ & $\begin{array}{c}5,75(1,4-23,49)^{\beta} \\
2,17(0,73-6,46)^{\beta} \\
1,59(0,54-4,62)^{\beta} \\
\text { Referensi }\end{array}$ \\
\hline $\begin{aligned} \text { Keterangan : } & { }^{`} \text { analisis s } \\
& \ddagger \text { Uji McNe } \\
& \text { ordinal } \\
& \alpha \text { bermakna } \\
\beta & \text { dds ratio }\end{aligned}$ & $\begin{array}{l}\text { ompok } \\
\text { lakukan untu } \\
\text { a statistik }\end{array}$ & nominal, L & $\log$ & ariat untuk data \\
\hline
\end{tabular}

Tabel 4. Durasi pemberian ASI saja tanpa makanan/minuman pendamping dan risiko autisme

\begin{tabular}{lcccc}
\hline \multicolumn{1}{c}{ Variabel } & $\begin{array}{c}\text { Kasus } \\
(\mathbf{n = 5 2 )}\end{array}$ & $\begin{array}{c}\text { Kontrol } \\
(\mathbf{n = 1 0 4 )}\end{array}$ & $\mathbf{p}$ & OR (RK 95\%) \\
\hline $\begin{array}{l}\text { Durasi pemberian ASI saja } \\
<4 \text { bulan }\end{array}$ & $\begin{array}{c}47(90,3 \%) \\
5(9,7 \%)\end{array}$ & $\begin{array}{c}94(90,4 \%) \\
10(9,6 \%)\end{array}$ & 0,69 & $1,27(0,38-4,24)$ \\
$\geq 4$ bulan & & & & \\
$\begin{array}{l}\text { Durasi pemberian ASI saja } \\
\text { tidak pernah }\end{array}$ & $15(28,8 \%)$ & $26(25 \%)$ & 0,61 & $1,86(0,36-3,45)$ \\
$<4$ bulan & $32(61,5 \%)$ & $68(65,4 \%)$ & 0,72 & $1,35(0,22-0,52)$ \\
$\geq 4$ bulan & $5(9,7 \%)$ & $10(9,6 \%)$ & & Referensi \\
\hline
\end{tabular}

Keterangan : ' analisis sub-kelompok

fUji McNemar dilakukan untuk data nominal, uji regresi logistik bivariat untuk data ordinal

menderita autisme. Pada kelompok ini, berat lahir rendah ditemukan lebih banyak dibandingkan berat lahir besar. Data ini menunjukkan bahwa bayi dengan berat lahir rendah memiliki risiko yang bermakna untuk menderita autisme. Faktor risiko lain yang ditemukan bermakna adalah usia kehamilan tidak normal. Tidak ditemukan perbedaan bermakna pada faktor perinatal yang lain.

Pemberian ASI kurang dari 6 bulan merupakan faktor risiko autisme (OR=2,01; RK 95\%:1,02-3,96). Terdapat dose-effect gradient pada durasi pemberian ASI yaitu semakin pendek durasi pemberian ASI, semakin besar risiko terjadinya autisme (Tabel 3). Pada subjek penelitian ini, tidak didapatkan perbedaan bermakna antara kedua kelompok pada durasi pemberian ASI saja tanpa makanan atau minuman tambahan (Tabel 4).

Faktor risiko yang masih didapatkan bermakna adalah durasi pemberian ASI kurang dari 6 bulan (OR=2,15; RK 95\%:1,11-3,89; $p=0,03$ ) dan riwayat berat lahir tidak normal (OR=3,36; RK 95\%:1,37-8,44; $p=0,01$ ) (Tabel 5). Analisis menggunakan uji Maentel-Haenszel dilakukan untuk mencari rasio odds durasi pemberian ASI kurang dari 6 bulan yang bebas dari faktor riwayat berat lahir tidak normal. Hasilnya menunjukkan bahwa durasi pemberian ASI kurang dari 6 bulan masih merupakan faktor risiko yang bermakna terhadap terjadinya autisme $\left(\mathrm{OR}_{\mathrm{MH}}=2,05\right.$; RK 95\%:1,03-5,01).
Tabel 5. Hasil analisis regresi logistik multivariat bersyarat

\begin{tabular}{lccc}
\hline \multicolumn{1}{c}{ Variabel } & OR & RK 95\% & p \\
\hline Pemberian ASI kurang dari 6 bulan & $2,15^{\alpha}$ & $1,11-3,89$ & 0,03 \\
Berat lahir tidak normal & $3,36^{\alpha}$ & $1,37-8,44$ & 0,01 \\
Pendidikan ibu sarjana/diploma & 1,95 & $0,75-3,45$ & 0,23 \\
Umur kehamilan tidak normal & 2,23 & $0,89-6,45$ & 0,28 \\
\hline
\end{tabular}

Keterangan : $\ddagger$ regresi logistik multivariat a bermakna secara statistik

\section{BAHASAN}

Pada subjek penelitian ini, anak yang diberi ASI kurang dari enam bulan berisiko menderita autisme dua kali lebih besar dibandingkan anak yang diberikan ASI lebih dari enam bulan. Pola menyusui berhubungan dengan risiko kejadian autisme. Hasil ini mendukung hasil penelitian yang dilakukan di Jepang (12) dan di Amerika Serikat (13).

Pemberian ASI yang direkomendasikan WHO adalah mulai dari lahir hingga anak minimal berusia 2 tahun atau lebih. Pemberian ASI memberikan manfaat untuk bayi, yaitu manfaat imunologi, nutrisi, dan psikologis. Manfaat imunologi diperoleh dengan adanya transfer antibodi terutama IgA dan komponen kekebalan lainnya seperti komplemen. ASI mengandung asam lemak rantai panjang yang berguna untuk perkembangan otak. Proses menyusui memberikan kedekatan emosional yang lebih baik antara ibu dan bayi dibandingkan pemberian susu formula 
melalui botol. Timbulnya kejadian autisme dihipotesiskan berhubungan dengan ketiga faktor ini yaitu meningkatnya kejadian infeksi (terutama gastrointestinal), gangguan fungsi otak karena defisiensi asam lemak rantai panjang, dan pengaruh psikologis (13).

Adanya hubungan kausalitas antara pola pemberian ASI dengan risiko autisme dapat diperkuat dari adanya hubungan dosis dan efek (dose-effect gradient) pada penelitian ini. Risiko kejadian autisme semakin meningkat pada kelompok yang tidak diberi ASI dibandingkan dengan kelompok yang pernah diberi ASI, walaupun secara statistik perbedaan yang bermakna hanya ditemukan ketika kelompok yang tidak diberi ASI dibandingkan dengan kelompok yang diberi ASI lebih dari 12 bulan. Meskipun begitu, adanya odds ratio yang semakin meningkat dengan semakin besarnya paparan menunjukkan kemungkinan hubungan kausalitas antara pola menyusui dan autisme.

Batasan durasi pemberian ASI saja pada penelitian ini ditetapkan pada usia 4 bulan karena perubahan kebijakan ASI eksklusif dari 4 bulan menjadi 6 bulan baru dilakukan tahun 2004. Kriteria inklusi sampel penelitian ini adalah anak dengan usia 3-10 tahun sehingga ada sebagian subjek yang lahir sebelum tahun 2000 di mana kebijakan ASI eksklusif masih ditetapkan selama 4 bulan. Kebijakan pemerintah tentu saja mempengaruhi perilaku kesehatan masyarakat. Berdasarkan penelitian referensi juga didapatkan bahwa ASI eksklusif selama 4 bulan mampu melindungi bayi dan anak dari infeksi gastrointestinal dan penyakit alergi dibandingkan pemberian susu formula $(3,16)$. Pemberian ASI eksklusif yang optimal mengurangi kejadian alergi makanan dan infeksi gastrointestinal pada masa bayi dan anak. Namun, hasil penelitian ini menunjukkan durasi pemberian ASI eksklusif bukan merupakan faktor risiko autisme.

Pada subjek penelitian ini, berat lahir tidak normal memperbesar risiko autisme secara bermakna. Berat lahir tidak normal (berat lahir $<2500 \mathrm{~g}$ atau berat lahir $>4000$ g) memberikan risiko tiga kali lebih besar dibandingkan berat lahir normal untuk menimbulkan kejadian autisme. Hasil ini sama dengan hasil penelitian di Amerika Serikat $(17,18)$. Bayi prematur atau berat bayi lahir rendah berisiko lebih besar mengalami asfiksia, infeksi, dan hiperbilirubinemia dibandingkan bayi normal. Faktor-faktor ini dapat mempengaruhi pertumbuhan dan perkembangan otak anak di kemudian hari (17).

Pada hampir semua penelitian kasus kontrol, bias ingatan (recall-bias) merupakan permasalahan utama. Bias ingatan mengenai pemberian ASI dikendalikan dalam penelitian ini dengan membatasi umur maksimal subjek penelitian yaitu 9 tahun. Bila memungkinkan, dilakukan pencocokan ingatan ibu dengan pengasuh yang lain, seperti ayah dan nenek subjek. Akurasi data menjadi hal yang penting dalam penelitian kasus kontrol. Rerata umur subjek pada penelitian ini adalah 5 tahun. Menurut hasil penelitian di Amerika Serikat, akurasi data ingatan ibu tentang pola menyusui pada saat bayi 5-10 tahun secara retrospektif adalah $60-70 \%$ (19).

Akurasi data pada penelitian ini dapat dicocokkan dengan survei epidemiologi terakhir yang dilakukan oleh Kementerian Kesehatan RI dalam Riset Kesehatan Dasar 2010 (Riskesdas 2010) (16). Persentase pemberian ASI hingga 12 bulan pada subjek penelitian ini sebesar $9 \%$ untuk kelompok kasus dan $22 \%$ untuk kelompok kontrol. Perbedaan yang didapatkan cukup jauh dibandingkan data Riskesdas 2010. Sedangkan pola pemberian ASI eksklusif masih dalam rentang yang sebanding dengan hasil survei Riskesdas 2010 maupun National Health Security Strategy (NHSS).

Durasi pemberian ASI pada populasi penelitian berbeda cukup besar dengan data Riskesdas 2010. Ada beberapa kemungkinan yang terjadi, yaitu terjadi bias misklasifikasi, artinya bahwa ibu pada kelompok kasus lebih cenderung untuk mengingat paparan yang dalam penelitian dihipotesiskan menyebabkan autisme atau penelitian hanya dilakukan pada populasi di daerah urban, sehingga mempengaruhi hasil.

Penelitian ini mendukung hasil dua penelitian di Jepang dan Amerika Serikat yang menyebutkan adanya hubungan antara durasi pemberian ASI yang tidak optimal dengan risiko autisme $(12,13)$. Ditinjau dari aspek kausalitas (14), aspek koherensi, hubungan dosisefek, kesamaan dengan penelitian lain, konsistensi, dan hubungan rasionalisasi secara biologis telah terpenuhi. Namun penelitian kasus kontrol tidak dapat menjawab apakah paparan mendahului efek atau sebaliknya. Asosiasi antara faktor durasi menyusui dan autisme dalam subjek penelitian ini juga tidak berkekuatan besar. Penelitian lanjutan dengan metodologi lebih baik harus dilakukan untuk mendukung aspek kausalitas adanya hubungan antara durasi menyusui dan risiko autisme.

Kelemahan penelitian ini adalah populasi kelompok kasus menggunakan prevalens (kasus lama ditambah kasus baru), bukan insidens (kasus baru), lokasi penelitian mengelompok pada daerah urban, tidak mewakili daerah rural, penetapan kasus hanya dilakukan oleh satu peneliti, sehingga terdapat kemungkinan bias seleksi, validasi pola menyusui pada populasi ini sulit dilakukan karena keterbatasan data nasional di Indonesia, dan tidak ada pembutaan pada saat wawancara responden.

\section{KESIMPULAN DAN SARAN}

Durasi pemberian ASI minimal selama enam bulan mengurangi risiko kejadian autisme. Hasil penelitian ini dipublikasikan dengan tujuan untuk memberikan motivasi bagi ibu menyusui untuk terus memberikan ASI pada bayinya dalam jangka waktu yang optimal. Penelitianpenelitian yang meneliti hubungan antara durasi menyusui 
dan risiko autisme perlu dilakukan terus untuk mendukung adanya hubungan kausalitas antara kedua faktor ini.

\section{RUJUKAN}

1. Blaxill MF. What's going on? the question of time trends in autism. Public Health Rep 2004;119(6):536-51.

2. Ratnawati H. Leaky Gut pada autisme. Dalam: Subagyo RJ, editor. Penatalaksanaan holistik autisme. Jakarta: Pusat Informasi dan Penerbitan Bagian IImu Penyakit Dalam FK Universitas Indonesia; 2003.

3. WHO. WHO expert consultation on the optimal duration of exclusive breastfeeding, recommendation for research. Geneva: WHO; 2001.

4. American Academy of Pediatrics. Breastfeeding and the use of human milk. Pediatrics 2005;115(2):496-506.

6. Arifeen S, Black RE, Antelman G, Baqui A, Caulfield L, Becker S. Exclusive breastfeeding reduces acute respiratory infection and diarrhea deaths among infants in Dhaka slums. Pediatrics 2001;108(4):67-75.

7. Carillo-Macias $C$, Marina-Franco $F$, Long-Dunlap K, Hernandez-Gaytan SI, Martinez-Lopez Y, LopezCervantes M. Breastfeeding and incidence of acute diarrhea in the first three months of life. Salud Publica Mex 2005;47(1):49-57.

8. Horwood LJ, Darlow BA, Moqridge N. Breastmilk feeding and cognitive ability at 7-8 years. Arch Dis Child Fetal Neonatal 2001;84(1):F23-7.

9. Hart L, Boylan ML, Carroll S. Breastfed one week old demonstrate superior neurobehavioural organization. J Ped Psych 2003;28(8):529-34.

10. Khedr EM, Farghaly WM, Amry-Sel D, Osman AA. Neural maturation of breastfed infant and formula-fed infant. Acta Paediatr 2004;93(6):734-8.
11. Kramer MS, Kakuma R. The optimal duration of exclusive breastfeeding: a systematic review. Geneva: Department of Child and Adolescent Health and Development WHO; 2002.

12. Tsai LY. Pervasive developmental disorders. Washington: National Dissemination Centre for Children with Disabilities; 2004.

13. Tanoue $\mathrm{Y}$, Oda $\mathrm{S}$. Weaning time of children with infantile autism. J Autism Dev Disord 1989;19(3):42534.

14. Schultz ST, Klonoff-Cohen HS, Wingard DL, Akshoomof NA, Macer CA, Ji M, Bacher C. Breastfeeding, infant formula supplementation, and autistic disorder: the results of a parent survey. Int Breastfeed J 2006;1:16. doi:10.1186/1746-4358-1-16.

15. Sastroasmoro S, Ismael S. Dasar-dasar metodologi penelitian klinis. Jakarta: Bagian IImu Kesehatan Anak Fakultas Kedokteran Universitas Indonesia; 2002.

16. American Psychiatric Association. Diagnostic and statistical manual of mental disorder-text revision. Psychiatrics 2000;11:12-32.

17. Badan Penelitian dan Pengembangan Kesehatan. Riset kesehatan dasar. Jakarta: Kementerian Kesehatan RI; 2010.

18. Nelson KB. Prenatal and perinatal factors in etiology of autism. Pediatrics 1991;87(5 Pt 2):761-6.

19. Piven J, Simon J, Chase GA, Wzorek M, Landa R, Gayle J, Folstein S. The etiology of autism: pre-, peri-, and neonatal factors. J Am Acad Child Adolsct Psychiatry 1993;32(6):1256-63.

20. Eaton-Evans J, Dugdale AE. Recall by mothers of the birthweights and feeding of their children. Hum Nut App Nutr 1986;40(3):171-5. 